\author{
O. Abdimanuly (iD), N.Zh. Dossanova* \\ Al-Farabi Kazakh National University, Kazakhstan, Almaty \\ *e-mail: kaznu.nazi@gmail.com

\section{KAZAKH POETRY OF THE EARLY XX CENTURY IN THE CONTEXT OF THE WORLD POETIC TRADITION}

The article discusses the problems of development of Kazakh written literature at the beginning of the XXth century and the prospects for the development of Kazakh poetry in the new century. At the beginning of the XXth century, the works of such poets as Akhmet Baitursynov, Mirzhakyp Dulatov, Magzhan Zhumabaev, who continued the traditions of the great Abay, were especially distinguished in Kazakh literature.

The main goal of the authors of the article is to identify Kazakh poetry of the early twentieth century in the context of world poetic tradition. Accepting the creative heritage of Baitursynov, M. Dulatov, M. Zhumabaev as unified artistic system, thereby revealing the essence of the concept of Kazakh literature of the early XXth century about the world and man.

The article also pays special attention to the definition of the creative features of each poet. In the poetry of M. Zhumabaev, the ability to convey the uneven, complex and contradictory dialectical process of the early twentieth century through a full-fledged artistic image is enriched by a deep analysis of the creative feature, which manifests itself as a form of artistic representation of reality.

The fact that the poetry of A. Baitursynov embodies a wide range of characters, covering all social groups of the Kazakh society, the desire to reveal the lives of people and a wide range of socio-philosophical problems of the era, proves that he was a real folk poet.

And the main feature of $M$. Dulatov's poetic creativity is that the main idea of M. Dulatov's poems follows from a deep study of the realities of life, his understanding and clear perception of political and social changes.

Key words: Alash, Kazakh literature, poetry, intelligentsia, poet, context.

\author{
Ө. ӘбАиманұлы, Н.Ж. Аосанова* \\ Әл-Фараби атындағы Қазақ ұлттық, университеті, Қазақстан, Алматы қ. \\ *e-mail: kaznu.nazi@gmail.com \\ XX ғасыр басындағы қазақ поэзиясы \\ әлемдік поэтикамық дәстүр аясында
}

Мақалада XX ғасыр бас кезіндегі қазақ жазба әдебиетінің даму мәселелері және қазақ поэзиясының жаңа ғасырдағы өркен жаюы жан-жақты қарастырылады. XX ғасыр бас кезіндегі қазақ, әдебиетінде ұлы Абай дәстүрін жалғастырған Ахмет Байтұрсынов, Міржақып Аулатов, Мағжан Жұмабаев сынды ақындар творчествосы ерекше көзге түседі. Олар қазақ жазба әдебиетінде азаттық, илеясын басты ұстаным еткен, азатшыл ағым қалыптастырды.

Мақала авторларының басты мақсаты - XX ғасыр басындағы қазақ поэзиясын әлемдік поэтикалық, Аәстүр мәнмәтінінде (контексте) анықтап, А. Байтұрсынов, М. Аулатов, М. Жұмабаев творчестволық мұрасын біртұтас көркемАік жүйе ретінде алып, сол арқылы XX ғасыр бас кезіндегі қазақ, әдебиетінің әлем және адам туралы тұжырымдамасының мән-маңызын ашу.

Сонымен қатар мақалада әр ақынның творчестволық ерекшелігін айқындауға да нақты назар аударылған. М. Жұмабаев поэзиясында XX ғасыр бас кезіндегі бір қалыпты емес, күрделі де қарама-қайшылықты диалектикалық үлерісті толыққанды көркем образ арқылы беру шеберлігі мен реальды шындықты көркем бейнелеу творчестволық ерекшелігі екендігін терең та^дау арқылы байыптаған.

А. Байтұрсынов поэзиясындағы қазақ қоғамының барлық әлеуметтік топтарын қамтыған сан түрлі характерлер сомдалуы, халық өмірін кеңінен ашуға ұмтылумен дәуірдің әлеуметтікфилософиялық мәселелерінің кеңінен қойылуы оның нағыз халықтық ақын ретінде қалыптастырғандығын нақты материалдар негізінде дәлелдейді.

А^, М. Аулатов өлеңдері негізіндегі түпкі ой оның өмір шындығын терең зерттеуімен саяси-әлеуметтік өзгерістерді түсінуімен айқын қабылдауынан туындап жататындығын ақын поэзиясының басты ерекшелігі ретінде қарастырады. 
Жалпы алғанда, XX ғасыр бас кезіндегі қазақ әдебиеті - қоғамдық сана мен адам психологиясы өзгерісінің, жеке адамдар тағдырының, қоғамдық-саяси жағдайлардың оқыс өзгерістік кезеңіндегі көркем шежіресі. Сол себепті де мақала авторлары осынау уақыт кезеңінде қазақ ақындары қоғамның рухани сұраныстарын нақты танып, жеке адамның қоғамдағы орнын айқындап, адамзатқа тән адамгершілік мәселесін жалпы ұлттық және әлемдік деңгейде көтергендігін жан-жақты әрі тиянақты түрде қарастырады.

Түйін сөздер: Алаш, қазақ, әдебиеті, поэзия, интемлигенция, ақын, контекст.

\author{
О. АбАиманулы, Н.Ж. Аосанова* \\ Казахский национальный университет имени аль-Фараби, Казахстан, г. Алматы \\ *e-mail: kaznu.nazi@gmail.com \\ Казахская поэзия начала XX века \\ в контексте мировой поэтической традиции
}

В статье подробно рассматриваются проблемы развития казахской письменной митературы начала XX века и возрождения казахской поэзии в новом веке. В казахской митературе начала XX века особенно выделяется творчество таких поэтов, как Ахмет Байтурсынов, Миржакып Аулатов, Магжан Жумабаев, продолживших традиции великого Абая. Они сформировали либеральное Авижение, что было основным принципом идеи свободы в казахской письменной митературе.

Главная цель авторов статьи - выявить казахскую поэзию начала XX века в контексте мировой поэтической традиции, взять творческое наследие А. Байтурсынова, М. Аулатова, М. Жумабаева как единую художественную систему, тем самым раскрыть значение концепции казахской литературы о мире и человеке в начале XX века.

В статье также уделено особое внимание выявлению творческой индивидуальности кажАого поэта. В поэзии М. Жумабаева прослеживается мастерство передачи диалектического процесса в начале XX века через полноценный художественный образ и глубокий анализ творческого своеобразия художественного воплощения реальной действительности.

Использование в поэзии А. Байтурсынова разнообразных характеров, охватывающих все социальные слои казахского общества, широкая постановка социально-философских проблем эпохи со стремлением к широкому раскрытию жизни народа свидетельствуют на основе фактического материала о его формировании как подлинного народного поэта.

Главная особенность поэзии в том, что основная идея, основанная на стихах М. Аулатова, проистекает из его глубокого изучения реалий жизни и ясного понимания политических и социальных изменений.

В целом, казахская литература начала XX века - это художественная метопись периода изменений общественного сознания и психологии человека, перемен судьбы отАельных людей, общественно-политических ситуаций. Поэтому авторы статьи подробно и обстоятельно рассматривают, как в этот период времени казахские поэты четко осознают духовные запросы общества, определяют место мичности в обществе, поднимают нравственные проблемы человечества на общенациональном и мировом уровнях.

Кмючевые слова: Алаш, казахская ^итература, поэзия, интемлигенция, поэт, контекст.

\section{Introduction}

Kazakh literature of the early twentieth century, having preserved its traditional ways of depicting human life and society, in new, rapidly changing socio-historical conditions, brought up the problem of philosophical understanding of the meaning of man and life to one of the main places.

What are human capabilities? What is his purpose in the modern world? These eternal questions again attracted the attention of artists of Alash literature in the early twentieth century - M. Zhumabayev, M. Dulatov, A. Baitursynov. Problems of the world and man became a living part of the literary experience in the Kazakh literature of this period.
Personality and epoch are the main theme of Kazakh literature of the beginning of the twentieth century. Man becomes the main subject of literature. Through the attitude of man to the objective world, he appears in all his concrete sensory richness and diversity. Man himself is both an object and a subject of artistic knowledge of the world.

The topicality of this article is caused by the need for a special study of the literary heritage of M. Zhumabayev, M. Dulatov, and A. Baitursynov in order to philosophically and aesthetically reveal the concept of the world and man in the Kazakh literature of the early twentieth century. The representatives of Alash literature had a particularly acute attention to the crisis condi- 
tions of Kazakh society and people of the early twentieth century.

Their works reflect ideological intentions in understanding the epoch and life of the Kazakh people in extremely broad philosophical categories, to reveal the relationship between the personal fate of the characters and social problems, the logic of their moral choice, the search for the meaning of life and ways of relationships with the world around them.

M. Zhumabayev, M. Dulatov, A. Baitursynov and their literary heroes assert in man the spirituality, the greatness of the restless spirit of the Kazakh soul. They as artists of their time showed the place of man in the eternal order of things, his search, vanity and care of everyday life in terms of unchanging postulates-life and death, his personal destiny.

The highest ideals of humanity must be embodied in the whole structure of life, in the fate, in the soul of the character they describe. Having mastered their meaning and imbued with their greatness, he can serve them with conviction through the awareness of his own destiny, preserving in himself a genuine humanity, freedom of spirit and strength of moral feeling.

The research topicality is caused by necessity of studying the regularities and peculiarities of the literary process of the early twentieth century, systematic and deep analysis of the works of M. Zhumabayev, A. Baitursynov in the context of the study of the conceptual perception of the world, of methods of creating literary reality and revealing the inner world of a person.

\section{Material and Methods}

The most important feature of the Kazakh poetry of the beginning of the twentieth century is that, recognizing the folklore and nationality as its ideological basis, it played a huge role in the formation of a new person, his worldview, his aesthetic consciousness. In addition, this period is characterized by the rise of realistic art in its relationship with the romantic form of displaying the surrounding reality.

In the poetry of M. Zhumabayev, the perception of life occurs through the opposition of his «I», the inner world of a person to real phenomena and processes of reality. For the creativity of M. Zhumabayev, it is not the description of phenomena, not the external features of human existence, but the secrets of his psychology, his spiritual collisions that are essential and interesting. In his poetry, the author's subjective moods and feelings are closely connected with the emotional experiences of his lyric hero, and often they completely merge. The essence of his artistic creativity is mainly in the expression of himself, showing the depths of the inner world of the Kazakh soul.

The creative research of the world involves not only an exceptional sensitivity to what is happening in it, but also the desire of the poet to penetrate into the essence of phenomena and processes, to fully convey the truth of life, to protect a person, to help him in his quest for freedom and happiness. M. Zhumabayev's poetry is an inquisitive study of reality and man, revealing the deep processes of life, the complexity of the inner world of people. The poet not only studies the reality and recreates it in artistic figures, but also intervenes in solving life's conflicts, revealing their origins and consequences, expressing his attitude to them.

M. Zhumabayev does not imitate reality, but creates a new reality. M. Zhumabayev's idea of the new reality coincides with the romantic and symbolic forms of perception of the surrounding world.

Zhumabayev, as a romantic, did not dream of improving the life partially, but of a complete resolution of all its contradictions. The discord between the ideal and reality, peculiar to the previous directions as well, acquires in his work an extraordinary sharpness and tension, which is the essence of the so-called romantic world duality.

The poet reveals the uncommon complexity, depth and Antinomian nature of the spiritual world of man, the inner infinity of human individuality. For him, man is a small universe, a microcosm. Intense interest in strong and vivid feelings, in secret movements of the soul, in the «night» side of it, craving for the intuitive and unconscious things are essential features of the romantic worldview. The protection of freedom, independence and inherent value of identity, the increased attention to the single, unique in man, and the cult of the individual are equally characteristic of the poet's romanticism.

M. Zhumabayev is not interested in short-term problems, he thinks about the fate of humanity, about the universe as a whole, he has his own personal perception of the world and the fate of his people. The lyric hero does not separate himself from the people, he is merged with them in joy and in sorrow.

If in the poems about «Korkyt», «Koylybay's Kobyz», «On the slopes of Okzhetpes» the poet touches on the history of the birth of philosophical thought and musical art of the Kazakhs, or tells about the real historical events of the national liberation uprising led by Kenesary and Nauryzbay, then in the poem «Batyr-Bayan» he talks about love. The poem «Batyr-Bayan» is a lyrical composition, 
although its plot is based on historical events: the struggle of the Kazakh khanate with the Kalmaks.

The author of the monographic works about M. Zhumabayev Sh. Yeleukenov, analyzing the poet's works, reveals the genre originality of the poem «Batyr-Bayan». He came to the following conclusion: «this is both a lyrical song about love, and an epic tale about the greatness of the spirit of the son of the Fatherland, and in the highest degree the tragedy of a man who did not have mercy even on himself in the name of justice».( Eleukenov Sh., 1997: 301-302)

The poem «Batyr-Bayan» is without any exaggeration a truly philosophical reflection of its author on the essence and meaning of human life, society, nature and existence, the role of sense and knowledge, and human activity. «The relationship of philosophical, artistic and spiritual principles is integral and organic in the work of M. Zhumabayev. Of the Kazakh word-painters of the beginning of the century, perhaps it is M. Zhumabayev who is the closest one to the paradigms of the national philosophy of life, religion, and nature». (Mamraev B., 1998: 38)

The accuracy of the description of nature or any life phenomenon is not in the abundance of details, not in the exactitude of transferring each feature. And the artistic task of the poet is not to make a copy, but to create the impression that a living picture would make on us.

For example, the description of the historical situation in the poem «Batyr-Bayan» is a true picture of real events of the 17th century. In one of the battles with the enemy, a strong and influential batyr of Abylai Khan, Batyr Bayan, once again, having defeated the enemy, brought a beautiful Kalmyk girl for himself. He loved her like a sister, never let anyone look at her. But the fate is cruel. Batyr-Bayan had a handsome younger brother Noyan, who took the fancy of the beautiful Kalmyk girl, and passion flares up between them.

M. Zhumabayev, telling the love story of the young man Noyan and the Kalmak girl, expands the boundaries of his reflections. The author writes not only about the state of being in love of his hero, but also about this feeling as a moral category of any person. BatyrNoyan, flooded by love passion, secretly runs with the Kalmyk girl to the enemy's side, thereby betraying his people and brother. No one can forgive betrayal, even if it is committed in the heat of strong feelings. The Khan's leadership orders Batyr to detain Noyan and the Kalmyk girl. He obeys the order, the Batyr's arrow catches up with the refugees. Bayan kills the Kalmyk girl and his only brother.
There is no doubt that in the historical poems the poetic skill of M. Zhumabayev was revealed in full. The picture of tragedy, even despair, the internal struggle between «Yes» and «No»; «to forgive means love», «not to forgive, means... «there is no answer» - all this complex of philosophical problems is solved by the author with the help of specific literary techniques and means. «Saturated with symbolic images, the figurative language of the poet's poems reflects a deeply assimilated romantic concept of being, cosmos of as phenomenal beauty, manifestation of love» (Maitanov B., 1996:39)

«Batyr-Bayan» is a conventionally romantic refraction of modern life. But the important and fundamental thing is that the subject of the artwork has become a modern thinking person. Before us there is a lyrical hero with his own fate and tragedy, that is individual, up to poetically transformed biographical facts, but with universal significance.

Not only the worldview plays an important role in artistic knowledge of the world. The entire multi-faceted sphere of the poet's spiritual potential, the degree of his talent, heightened sensuality, life experience and outlook, penetrant observation, which developed the ability to create deeper and broader generalizations of life phenomena, more fully and vividly comprehend the objective truth of being in its concrete-sensory reflection. (Esembekov T.U., 2014:230)

The national world and the concept of the formation of authentic high artistic value can not be considered outside of the features of the formation of national consciousness, poetic character, traditions of Kazakh authentic high artistic value and the originality of the author's artistic vision and image of reality.

The moral and humanistic elements exist within each national culture as a real flesh, as a historical product of the social existence of the people. The universal and all-human nature of literature is expressed in each of its national forms. National culture, bearing the universal content, the ideas of equality, friendship, the idea of fighting for human happiness, thus joins the greatest movement of modernity, enters the world literature, contributes to its artistic development.

Every time certain phenomena, processes, events are involved in the sphere of human interests, in true reality, all new aspects of life become the subject of artistic knowledge. That is why it is the person who becomes the main subject of poetry, and talent transforms the relationship between man and objective reality into the artistic world, presenting it 
in all its concrete-sensuous richness and diversity. (Ospanova A., 2014:210)

The bright influence of universal mind combined with the depth of the idea, wise cheerfulness made M. Zhumabayev an original thinker, a passionate poet, a great Creator, the tragedy of whose life revealed both his beliefs and his character.

The direction of symbolism is associated with the name of Magzhan Zhumabayev in Kazakh literature, although symbolic worldview is a traditional form of artistic vision of the Kazakhs, for example, any work of folklore (ritual poetry, zhyr, tolgau, aitys, aphorisms, fables, parables, etc.) contains an inner thought, the essence of folk philosophy, expressed in symbols, stereotypes of syncretic thinking, that is, many genres are united and distinguished by one detail - the presence of a deep subtext, figurative hint, that is, symbols. In addition, «the symbolic vision of the world has always been inherent in Kazakh poetry» (Maitanov B., 1996: 187)

In our opinion, M. Zhumabayev's symbolism is a peculiar form of artistic representation of the complex, contradictory reality of the beginning of the 20th century, the desire to show an ambiguous dialectical process in full-fledged artistic images. $\mathrm{Zh}$. Aimauytov believes that «the symbolism of Magzhan is the influence of the older generation of symbolists, in particular Balmont» (Aymauytov Zh., 1989: 415). This opinion is also shared by Sh. Yeleukenov. «In the poem «The Prophet» the main idea [the opposition of the West and the East] is developed from the quatrain of D. S. Merezhkovsky: «Fixing our eyes, At the fading East, Children of sorrow, children of night, We are waiting for our prophet to come...» (Eleukenov Sh., 1997: 298)

Most likely, Zhumabayev, creating his poems of symbolic direction, takes as a basis the ideological and figurative system of the Balmont cycle «Let's be like the sun», full of sincere faith in art and human freedom.

The fiery poetry of Magzhan Zhumabayev fits in this sphere of poetic sincerity. By virtue of the genuine power of his talent he continues this brilliant constellation of poets of the twentieth century, that takes its origins from the stellar aspirations of F.I. Tyutchev, A.S. Pushkin and A.A. Fet, A. Blok, O. Mandelstam, from the German star lyrics of M. Cladius, H. Heine and global poetic traditions P. Verlaine, A. Rimbaud, etc. (Robert N. 2001: 55) But at the same time, he does not lose his national identity, traditions of nomads, who also embraced the cosmos, the sun, the sky and the stars with their art. Zhumabayev's poem sarefulloffireandlight. They are magnificent, bold, and noble. Therefore, in the poems the poet borrowing motives, gives his solution to socio-political, moral and philosophical problems. «Balmont's cycle of poems «Let's be like the Sun»- a kind of anthem to the Sun and Fire and a call to humanity, played a role in the development of the «cosmic» theme in Russian literature. Further, this theme was developed in the collection of poems by A. Bely "Gold in Azure», V. Ivanov «Sunheart», in the works of N. Roerich. The creation of the mystery of Fire and Sun by symbolists was based on utopia about the life-building role of art». (Ivanov V., 1912: 9) This idea intersects with the worldview position of M. Zhumabayev. The poet creates a cycle of poems that reflect and find the solution to the burning problems of the time - the beginning of the $20^{\text {th }}$ century. M. Zhumabayev uses the symbolism of Fire, Sun, Moon with one goal - to transform the world. The poet dreams of the triumph of justice, freedom, and love in the world. Hence, in his poems, the symbols of Fire, Sun, West-East represent the protest and struggle for a better world, the protection of man and humanity. «Fire», «Prophet», «East». The poetic symbolism of M. Zhumabayev is characterized by the fact that the interaction of man and nature, the application of it by people, their connections with each other develop on the basis of a relatively adequate reflection of the phenomena of reality by the human consciousness. On the other hand, the poet wants to penetrate more and more deeply into the secrets of nature, the inner world of man. Symbolism of M. Zhumabayev, as a way of artistic development of reality, embodies human notions and ideas, in the form of an artistic figure, reflects the processes taking place in the world, in people's lives. The poet seeks to bridge the gap from the individual state to the whole world, to establish the connection of this moment with life in its cosmic meaning. The feeling of depth, space, distance, characteristic of $\mathrm{M}$. Zhumabayev, more and more passes into the feeling of infinity and is filled with a proper philosophical meaning: Dawn is coming from the East, I'm coming, Heaven is in sorrow, and I feel aggrieved together with the sky, In total darkness the Earth is delirious, I'll light up the whole earth, present the Sun...(word - based translation of the author).

Poetry creates a picture of the objective world precisely as a picture of man's creative learning the world, and thus of man's self-development (selfrealization) in the world as his creative, transforming power; the world does not satisfy man, and man decides to change it by his action.

The sphere of human knowledge is the entire multi-sided and diverse reality. The emergence and 
formation of various forms of social consciousness is due to the objective necessity of historical development, the diversity of the material and spiritual reality of the world that a person learns, including the self-identity of a self-knowing, selfasserting individual.

The main role of a creative person in creating a conceptual picture of the world is manifested in the peculiarities of his artistic interpretation of the world and human, in creating a special reality, in selecting methods and principles of historical, social, moral and philosophical understanding of life.

The subject of literature, the sphere of its cognitive efforts is the living, dynamic integrity of the world in its self-development and selfmovement, in contradictions, relationships, in its real materiality and spirituality. Whether it is a phenomenon of nature or social existence, each of them is reflected in the artistic consciousness as a living concrete-sensory image, in which the multifaceted integrity of the world is clarified.

The artistic genius always strives to learn about the objective reality and, at the same time, to search and comprehend the true, adequate for the subject of understanding forms and means of artistic development of this reality, its creative understanding and re-creation into an art phenomenon. The truth of reality becomes true only when it acquires the living flesh of a concrete-sensory image, emerging as an aesthetic ideal imbued with humanistic pathos, a harmonious unity of truth and beauty of the artistic whole. (Berikbolova P., 1914: 190)

The poetic art of A. Baitursynov is of great importance for studying the literature of the $20^{\text {th }}$ century. The interrelation of philosophical-aesthetic, artistic and spiritual principles characterizes the peculiarity of his poetic creativity. Inclination to the moral and spiritual origins of Eastern culture, to the ideological and aesthetic search for Russian literature are inherent to his poetry. The poet does not avoid traditional folk images, strives for broad realistic generalizations of the world picture, reflects the humanistic concept of being.

Based on the creative synthesis of achievements of Russian literature, national poetic traditions, and the experience of Eastern poetry, the poet created a genre system of poetry that meets the spirit of the time, worked out the forms and principles of the image of individual. The analysis presents that the issue of moral and philosophical strivings organically developed in his poetry, creating the conceptuality of ideological and artistic searches. The collection «Forty fables» by A. Baitursynov consists of the poet's own works and the translation of I. A. Krylov's fables. M. Auezov wrote about the collection «Forty fables»: «For the broad masses of the Kazakh people, the collection «Forty fables» was the first book that carries the revolutionary spirit. After that, A. Baitursynov became known as a person deeply worried about the people» (Barlybaeva G., 2020: 70) A fable is a genre of didactic literature; a short story in verse or prose with a directly formulated moral conclusion that gives the story an allegorical meaning. This is a poetic story-event in which the characters are usually animals, inanimate objects. (Encyclopedic Literary Dictionary, 1987: 751) The purpose of the story is some moral truth presented in action and, consequently, awakens in us both feeling and imagination. It takes a real image in our eyes, leaves strong, long-lasting impressions. (Belinsky V.G., 1981: 438)

First: a fable is a moral in action; there are the general concepts of morality in it, they are applied to a particular case and are thereby made more perceptible. The reality that is reflected in the fable is a mirror image of the human world.

Animals represent human in the fable. As if the properties inherent in wolf, bear, or rooster are transformed into human ones, and it is not difficult for us to imagine in this image our friend, relative, or accidentally met person. In a wolf we see a man who brings evil and violence, in a fox - a flatterer or deceiver. And there is no need to waste words, the picture of life is in the palm of your hand. By transferring the reader's imagination to an imaginative, fantastic world, the fable gives him the pleasure of comparing the fictional with the existing (to which the former serves as a semblance), and the comparison makes the moral itself attractive.

Fable is a moral lesson that gives human through the creation of artistic images of animals, inanimate things, showing as an example the actions of creatures that are different from man and nature, completely alien to him. Thus it spares a person's self-esteem, makes him judge impartially, and he unconsciously pronounces a strict sentence on himself.

In order to take a lively part in the conflicts created by Baitursynov and make them interesting for any reader, one should have that natural sensitivity of a pure heart, that fullness of soul, that favour to kindness, which helps us to see the beautiful thing in society and in nature.

If Krylov's fables determine the main aesthetic laws of fable, then A. Baitursynov uses these laws for a realistic representation of the Kazakh reality of the beginning of the $20^{\text {th }}$ century. The poet translates Krylov's fables, in which he wanted to be not just a 
moralist, but a virtuous poet who not only reveals the evils of reality, but also provides ways to correct people and society's morals. Baitursynov's fables directly give an answer to what a true teacher of life, a true leader of public opinion, a truly worthy writer of a high title, a guard of society moral should be. The poet considers satire one of the main means of education. A. Baitursynov was convinced that laughter and irony are the main means of forming the Kazakh analytical consciousness. It is laughter and ridicule that makes it possible for the Kazakh to see his own vices, understand the inhuman mores of society, and thus open the way to change himself and society. The author consistently adheres to the classical rule, that is, his fable consists of a story and an explanatory moral. Moreover, the moral of Baitursynov's fables is a separate conclusion, which looks like a moralizing poem that ends the fable. In addition, it gives the reader the position of the author to the fable story and makes a conclusion. (SadykovN., 2013: 693).

The poet's fables are distinguished by their plot movement, detailed character development, and lively dialogues. The story turns out to be so individual and, at the same time, typical that the expressed «morality» is perceived by the reader as a real truth: ...There are many different people in the world, (...Дүниеде түрлі-түрлі адамдар бар), some of them are good and some are bad. (Жақсы да, арасында жамандар бар). Even when they use the science. (Ғылымды пайдаланып отырса да), There are illiterate ones do not know all its benefits. (Сезбейтін сол пайдасын надандар бар).Wordbased translation of the author. (Baitursynov A., 1989: 45).

A. Baitursynov's fables offered their own solution to the general literary tasks assigned by the time and level of national consciousness of a certain historical epoch. It was necessary to understand the meaning of history, the conditionality of its human activity and needs, the correlation of spontaneous development, conscious will or arbitrariness of man.

A. Baitursynov writes about the possibilities of a life-creating mind that is necessary for solving a national problem. The task of fable poetry is not to recreate the event itself, even if it is very significant, but to clothe it with poetic thought, to convey its moral essence. In the poems of A. Baitursynov, intense human thought and the endlessness of the search for truth: the problems of good and evil, humanity and anti-humanity live and pulsate. The point at issue is a particular poetic word that can convey the movement of thought, the life of the human mind, its interaction with the surrounding world. Poetry of this rationalistic type is differentiated with high intelligence and beauty of logical thinking itself.

A. Baitursynov's humanism defines the artistic strivings of the poet, whose entire creativity is directed to the image of a free person. In addition, the basis of his creative idea is formed by observations of reality, impressions received by him as a result of socio-historical events, certain phenomena of life.

Creating artistic figures, the poet starts from the perception of life, from concrete phenomena of reality. He does not abstract and declare life. A. Baitursynov goes through a difficult path of artistic reproduction of reality in all its diversity, complexity and ambiguity.

The author's conceptual idea and national identity reveal the event dynamics of the artistic world, transforming reality, revealing the artistic originality of the creative world in the aspect of interaction between man and society.

The new conceptual idea of man defined the meaning, content, and entire character of A. Baitursynov's work. What should be the poetry that transforms a person?

This complex problem troubled the poet even in the early period of creativity. No matter what the poet wrote about, no matter what subjects and human destinies he chose, he still had the idea of man as the main way of understanding the reality. It, worn-out, endured by him many times and variously implemented in his poetry, at the same time became the common property of the literature of critical realism. In the process of creativity, A. Baitursynov, mastering different forms of embodying the image of the people, masterfully combined the image of the mass with a deep insight into the world of an individual.

A. Baitursynov doesn't just reflect the level of understanding of humanistic ideas. He develops them, fights for them, thereby contributing to the moral progress of mankind. The problem of humanism remains one of the most acute ones in his work, both because the list of crimes against humanity does not go out, and because the world cannot overcome the crisis of moral principles. The «moral vacuum» cannot be filled by the numerous communist aesthetic systems that proceed from the inviolability of socialism.

A significant event in the cultural life of the Kazakh society was the collection of poems by Akhmet Baitursynov «Masa», «Mosquito», published in Orenburg in 1911. The ideological orientation of the poems is defined in the title. The poet's task is to awaken his people with the help of word, like a mosquito that gives no rest: Maybe he'll 
wake up, (Ұйқысын аз да болса бөлмес пе екен), From the annoying buzzing in his ear. (Word-based translation of the author) /(Қоймастан құлағына ызыңдаса?) (Baitursynov A., 1989: 23).

The ideological orientation of the poems is the promotion of educational ideas. The poet believes that only knowledge, culture, and poetry can somehow change the life of people. Will you continue to live like this? - asks the poet. Won't you wake up, won't you get up? «Happiness», «Wish». A. Baitursynov's poetry answered to educational activities with a spiritual and political orientation. His lyrics are characterized by a tendency to combine the ideas of humanism with the political struggle to awaken the national consciousness of the Kazakh people. An another aspect of this problem is the struggle against age long ignorance, spiritual dormancy, lack of will and inaction. The poet actualizes the issues of culture, literature, and education before the public consciousness.

A. Baitursynov's work captures an entire epoch of Kazakh history. None of his contemporaries managed to cover the real life and national life of the time of colossal social and historical upheavals in such a wide, diverse and artistic way. Many characters created by the poet, representing literally all social layers of Kazakh society, the depth of penetration into the life of the people and the breadth of setting the social and philosophical problems of the era make A. Baitursynov a national poet. Studying life, capturing it in artistic figures, A. Baitursynov does the most subtle and complex work on selecting and highlighting the significant, interesting things. He carries out a deep work on the analysis of the reality phenomena, their synthesis. In this process, undoubtedly, a very important role is played by the nature of the poet's understanding of the surrounding world. The features of creative learning the reality are shown not only in that what aspects it has, what phenomena and events attract the attention of the poet; they are also clearly expressed in that what he considers essential and characteristic in contemporary life or history, in what he sees the sublime and the base, the comic and the tragic.

M. Dulatov's creative idea is most often based on his research of the reality, understanding and perception of life phenomena, social and political events. As a rule, the writer's attention is drawn to specific facts of life that have struck his creative imagination, events, and people, but the artistic idea does not germinate instantly or spontaneously, but gradually, often arising in the process of painful artistic strivings and reflections.
Creating artistic figures, M. Dulatov does not start from general logical premises, but from the perception of the fullness of life, not from abstractions, but from concrete phenomena of reality. This is typical for M. Dulatov, and for the artists of the early 20th century, who from the very beginning clearly understand and form the idea of their work. The idea of an art work can be actually and directly related to impressions acquired from specific events, but often, the life observations of $M$. Dulatov, that were the impetus for the emergence of the idea, become contradictory, and their relationship with the creative idea is much more mediated and complex.

The experience of the present and the past time in the work of M. Dulatov seems to be passed through the prism of the main political events of the era and is therefore full of significant modern significance. Recreating the intense feature of the reformation of national life and psychology, the poet in different angle reveals the main truth of the history - the ratio of the national and universal one. In the light of this objective criterion, he reconsiders public ideas about virtue and evil, benefits and harm, explaining the social nature of human inequality and immorality.

Putting the topical issues of his time in the center of artistic creativity, solving the problems of universal significance, M. Dulatov develops a new artistic concept of personality, different from the traditional spirit of submission and social indifference.

The poet, developing an artistic concept of the world and human that meets the needs and conditions of modern world, combines different in themes, style and character works, uses for this purpose the most effective aesthetic solutions and forms, perceived from the national creative experience, and distinguished in the course of national history.

The first poem by M. Dulatov was published in 1907 - «Zhastarga» («To the youth»), then in 1909 a collection of poems «Oyan, Kazakh» («Wake up, Kazakh!») was born. The collection of poems «Wake up, Kazakh!» M. Dulatov prefaces with his introductory article, in which he talks about the state of modern Kazakh society. He draws the readers' attention to the fact that «the world is undergoing great changes, the main thing is the movement towards science, education, and culture. And only the Kazakh people seem to be aloof from these events and phenomena. The author is talking with readers about the history, traditions, customs of the Kazakh people: «Kazakh turaly» («About the Kazakhs»), «Kazakh halkynyng buryngy ham bugingi hali» («Kazakh yesterday and today»), 
"Sailaularhakynda» («About elections»), «Kazakh zherleri» («The land of the Kazakhs»), and then makes a profound conclusion - it is not possible to go on living like this (Dulatov M., 1991: 355).

The history of the past is necessary for the poet to compare, so that the people remember his lessons, realize their mistakes, faults, omissions. M. Dulatov teaches to evaluate life situations and critically treat their own merits.

The author gives a real picture of what has happened to the Kazakh people that were once great today: The poems «Nasikhat» («Agitation»), «Tarshylyk halimiz hakynda az munazhat» («Reflections on the oppressed people») express the civil position of M. Dulatov, his poetic credo. They present a monologue of the poet - lover of truth, the poet - defender of the people.

In realistic literature, the inner world and behavior of characters are formed on the basis of the peculiarities of their time. M. Dulatov often shows the direct dependence of social, moral, religious beliefs of characters on the conditions of existence in a given society, pays great attention to the social background of time. And yet in his realistic art, circumstances are depicted only as a necessary prerequisite for the disclosure of the spiritual world of people. The main cognitive value of the writer's realism is the depiction of the characters and integral spiritual life of the individual, the identification of the system of feelings inherent in different types of personality, spiritual dramas - in short, all that makes up the life of the human spirit.

M. Dulatov is an artist who persistently and patiently examines the character, revealing the unfading human values hidden under it. He does not judge a person in one line. Even in the most simple cases, it would seem, he looks into the depths of the human soul, discovers its underground flow. And in this humanistic feature of his talent, there is a foretaste of the complex spirituality of folk characters.

The works included in the collection of poems by M. Dulatov touch upon the problems of contemporary life that meet the present-day concerns. The poet reflects on the power, gives a vivid picture of unfair elections of the volost, slashes at those who seek to get the rank of the volost by any means in the poem «Sailaularhakynda» («About elections»).

In addition, this collection includes poems that reveal one of the main themes in the poet's poetry - the slave status of Kazakh woman, her fate and her desire for happiness. In the poem «Zhesir dagualaryk hakynda» («On the natters of the law of widows»), the author gives a realistic picture of the heavy burden of Kazakh women, claiming that this is a topical, acute, modern problem. The main idea of M. Dulatov's poems is to awaken the consciousness of the people, reveal their desire to rebuild society and life, call them to fight for their freedom, prosperity, and happiness.

The collection of poems «Azamat» («Citizen») is remarkable in its content. If in the collection «Wake up, Kazakh!» the themes of educational and agitation character, didactic ideas, satirical poems prevailed, then the collection "Citizen» is the top of the poet's artistic perfection and skill, an indisputable argument in favor of his extraordinary poetic talent, a clear evidence of the consolidation of critical realism as an artistic method of displaying and evaluating the surrounding reality.

M. Dulatov is a talented lyricist. His poetry is a significant phenomenon in the Kazakh poetic culture. The poems «Armanym» («My Dream»), «Kiyal» («Fantasy»), «Myng» («Sadness»), «Tan» («Morning») define the ethical and aesthetic position of the author. Poetry, artistically reflecting the real world, helps a person to understand high art, ideals, become cleaner, more beautiful, softer and kinder. The peculiarity of M. Dulatov's aesthetic views is a peculiar belief in the power of the poetic word. He is convinced that the poet can wake up the people, raise them to fight for their freedom and happiness, overcome evil, destroy ignorance.

M. Dulatov's poetic techniques are characterized by conciseness, laconicity, objectification of feelings and experiences, that increases their emotional impact. The poet's lyrics are psychologically rich and meaningful. It realistically conveys human feelings and experiences, the movement of the heart, changes in feelings. His lyrical poems are an example of restraint. At the same time, his original comparisons and contrasts, epithets, peculiar metaphors and various poetic figures impress with their originality and reflect the personality of the poet, his subtle mind and soul.

\section{Literature review}

Kazakh and so-called Alash literature of the beginning of the twentieth century as an object of scientific study was already defined in the works of M. Auezov, S. Seifullin, S. Mukanov, G. Tokzhanov, E. Ismailov and others. The works of B. Kenzhebayev, B. Shalabayev, I. Duysenbayev, S. Kirabayev, A. Derbisalin, M. Bazarbayev, Sh. Eleukenov, R. Berdibayev, T. Kakishev, M. Karayev, Z. Bissengaliyev, and others were devoted 
to various aspects and problems of literature of the studied period.

In the late 80 's, there were fundamental works by S. Kirabayev, Z. Akhmetov, Sh. Eleukenov, M. Bazarbayev, T. Kakishev, Zh. Ismagulov, K. Mukhamedkhanov, R. Nurgali, and other authors.

In terms of studying the literary heritage of individual poets and writers in particular, the literary process of the beginning of the twentieth century as a whole, in addition to the above mentioned ones, the works by O. Abdimanuly, B. Maitanov, B. Mamrayev, A. Ismakova, B. Abdigaziuly, A. Zhaksylykov, B. Zhetpisbayeva, R. Sagynbekuly, T. Yessembekov, U. Kalizhan, B. Omarova, D. Kamzabekuly, B. Kanarbayeva and others present certain interest.

The works of Sh. Yeleukenov are especially valuable. It provides an example of a holistic analysis of the life and work of repressed poets and writers. In addition, the author defines the role and significance of A. Baitursynov's social and scientific activities in the history and culture of the Kazakh people. Research by Sh. Yeleukenov and M. Zhumabayev is a major contribution to modern Magzhan studies.

The relevance of the problem is evidenced by the fundamental works of R. Nurgali, which emphasizes the need for a systematic study of the literary process of the early twentieth century, the development of a new view of the problem of «history and literature». R. Nurgali, choosing the work of the representatives of Alash literature as the subject of scientific research, gives an ideological and thematic analysis of their literary works, at the same time pays special attention to the study of the regularities of the literary process, analyzes the genre forms in the works of these writers.

The works of D. Kamzabekuly are theoretically significant. They define a new direction in the study of this problem, present a new look at the literature of the early XX century, and justify the methodological basis for the study of the heritage of the repressed poets and writers.

The works of O. Abdimanuly about the literary heritage of A. Baitursynov brought a lot of new things to the methodology of the poet's creativity research.

The purpose of our research is to define the Kazakh poetry of the early twentieth century in the context of the world poetic tradition, analyze the creative heritage of M. Zhumabayev, M. Dulatov, and A. Baitursynov as an artistic whole, and reveal their concept of the world and man in the Kazakh Literature of the early twentieth century.

\section{Results and Discussion}

In the works of M. Zhumabayev, A. Baitursynov, M. Dulatov, in the midst of particularly intense and acute thoughts about the essence of the national character, the historical fate of the nation and its prospects, the image of the "seeder of humanity» is derived, which will help to eradicate evil and immorality in the Kazakh society, establish justice and equality, help the Kazakh to achieve freedom and happiness. Mind, as represented by all these artists, has a remarkable capacity for understanding life. They are the poets of their time, they sought to learn reality through its integral perception and experience.

The power of true realistic creation, as we know, lies in the discovery of new things in the world around us.

A. Baitursynov's fables offered their own solution to the general literary tasks assigned by the time and level of national consciousness of a certain historical epoch. It was necessary to understand the meaning of history, the conditionality of its human activity and needs, the correlation of spontaneous development, conscious will or arbitrariness of man.

The world of M. Dulatov's poetic figures, their objective meaning is immeasurably broader and more diverse than his political beliefs. M. Dulatov reveals the socio-moral problem of human and society, the relationship of human and time in a peculiar way. Showing the dependence of a person on circumstances, he simultaneously emphasizes the moment of conscious choice, which is faced by a $n$ active-minded person who wants to find his place in life, his true happiness. In the discription of the psychology of a character, the poet reaches a great saturation of images, drawing the most different aspects of human behavior, his attitude to nature, to certain phenomena of life, to people. His works have deep psychological roots in the creation of characters that come from the national tradition and folklore.

Having mastered the best traditions of his predecessors, combining them with the achievements of Russian and world literature, M. Zhumabayev makes a truly evolutionary leap in the development of national literature, giving it a wealth of ideas, themes and motives that was unknown before, immeasurably expanding its artistic horizons and enriching it with a variety of poetic forms and genres. The new concept of human defined the meaning, content, and entire character of M.'Zhumabayev's work, it, being worn-out, endured by him repeatedly and variously implemented in his poetry, at the same 
time became the common property of literature of a romantic nature. In the process of creativity, A. Baitursynov, mastering different forms of embodying the image of the people, masterfully combines the image of the mass with a deep insight into the world of an individual.

Kazakh literature of the beginning of the $20^{\text {th }}$ century was an artistic chronicle of socio-political vicissitudes, the breakdown of public consciousness and psychology, the drama of personality. At the same time, it reflected the spiritual needs of society, raised to the rank of national and world problem of the human personality, the problem of moral improvement of mankind.

The peculiarity of each literature is determined, first of all, by the concept of the world and human that that is the basis of it. The concept of the world and human at each historical stage acquires new features and qualities. The power of the great master of words is not in the fact that he perceives the existing concepts and embodies them, but in his independent search for a deeply truthful and impressive reflection of reality, in the original disclosure of its new aspects, its development.

\section{Conclusion}

The works of M. Zhumabayev, M. Dulatov and A. Baitursynov show a common desire to understand human life in extremely broad philosophical categories, to link the personal problems of the characters with the universal problems of human existence, the search for the meaning of life, moral behavior and attitude to the surrounding social world. It is obvious that for M. Dulatov, A. Baitursynov and other poets, their contemporaries, poetry was the fulfillment not only of their personal, but also of the historical true purpose of the epoch. Their poetic form breathes a freshness that cannot be found in the poems of the early period, here the triumph and joy of artistic discoveries are heard. Poetry becomes an act of being, it is full of sincerity and faith in art.

\section{Әдебиеттер}

Елеукенов Ш. Әдебиет және ұлт рухы. — Алматы: Ж.Ш.С.Жалын, 1997. —368 б.

Мамраев Б. Основные тенденции развития казахской литературы первой четверти XX века. - Алматы: Ғылым, 1998. $-262 \mathrm{c}$.

Robert N. Twentieth-century poetry. Blackbell publishing, 2001. - pp. 610

Майтанов Б. Қазақ романы және психологиялық талдау. - Алматы: Санат, 1996.

Esembekov, T.U., Kozhakanova, M.T. The Social Nature of Literary Translation in Kazakstan in XX Century. Procedia - Social and Behavioral Sciences 114 (2014) p. 229-233

Ospanova A. (2014) The idea of Turkic unity in Kazakh poetry of the early twentieth century. Almaty, Life Science Journal, $11 / 8 /$ p. $207-211$

Аймауытов Ж. Мағжан Жұмабаев. В кн.: Мағжан Жұмабаев.Шығармалары. - Алматы: Жазушы, 1989. - 415 б.

Иванов В. Мысли о символизме // Труды и дни, 1912, N1. - 9;

Berikbolova P., Abiyr A., Aydogdu S. (2014 )122 History of Kazakh Literature Classification. Elsiver/ Procedia - Social and Behavioral Sciences / Science Direct 2nd World Conference on Design, Arts and Education www.sciencedirect.com. p.p. 189 - 193 Литературный энциклопедический словарь. - М.: Советская энциклопедия, 1987. $-751 \mathrm{c.}$

Белинский В. Г. Полное собрание сочинений в 9 т-х, т. 7-1981. т. 7. - С. 438

SadykovN., Zhussipova A., Abdimanuly O. (2013) Kazakh Literature in Emigration and Works of Mazhit Aitbayev. World Academy of Science, Engineering and Technology International Journal of Humanities and Social Sciences.Vol:7, No:3, 2013 pp. 690-695

Байтұрсынов А. Шығармалары. - Алматы. Жазушы, 1989. - 317 б.

Дулатов М. Шығармалары. - Алматы: Жазушы, 1991. —-380 б.

Abdigapparova Zh. Liberation ideas in works of Alash activists. — Baku: 2018. Chapter 1, 1032 pages Number of pages 1038, ISBN 978-9952-3706-5-2, Published- May 21.

Nusipjanova B. Identification of mental types of the kazakh culture in the context of euroasian civilizations. Man In India, 96 (12): 2012. p.5585-5595 (C) Serials Publications

Barlybaeva G. Kazachų etikos istorija / The history of ethics of Kazakhs. https://doi.org/10.24101/logos.2020.28 Balandis $\backslash$ Birželis, 2020, p.p. 67-80

Compton-Rickett A., M.A., LL.D. A History of english literature. London:T. C. \& E. C. Jack 67 Long Acre, W.C., and Edinburgh New york: Dodge publishing co, 1900, p. 112. 


\section{References}

Aumauytov Zh. (1989) Magzhan Zhumabayev. Shygarmalary [Magzhan Zhumabayev. Works]. Almaty. Writer. p. 415 (In Kazakh)

Abdigapparova Zh.. (2018) Liberation ideas in works of Alash activists. Baku, Chapter 1, 1032 pages Number of pages 1038, ISBN 978-9952-3706-5-2, Published- May 21.

Baitursynov A. (1989) Shygarmalary [Works of art]. Almaty. Writer. p. 415 (In Kazakh)

Barlybaeva G. Kazachu etikos istorija \The history of ethics of Kazakhs. https://doi.org/10.24101/logos.2020.28 Balandis $\backslash$ Birželis, 2020, p.p. 67-80.

Belinsky V.G. (1981) Polnoe sabranue soshinenii [Complete works]. Part 9 (Volume 7). p. 438 (In Russian)

Berikbolova P., Abiyr A., Aydogdu S. ( 2014 )122 History of Kazakh Literature Classification. Elsiver/ Procedia - Social and Behavioral Sciences / Science Direct 2nd World Conference on Design, Arts and Education www.sciencedirect.com. p.p. 189 - 193 Dulatov M. (1991) Magzhan Zhumabaev. Shygarmalary. [Magzhan Zhumabaev. Works of art]. Almaty. Writer. p. 380 (In Kazakh)

Mamraev B. (1998) Osnovnye tendensii razvitiya kazhskoi literatury pervoi chetverti XX veka [Main trends in the development of Kazakh literature in the first quarter of the XX century]. Almaty. Science p. 262 (In Russian)

Maitanov B. (1996) Kazah romany jane psihologiyalyk taldau [Kazakh novel and psychological analysis]. Almaty. Sanat (In Kazakh)

Nusipjanova B. (2012) Identification of mental types of the kazakh culture in the context of euroasian civilizations. Man In India, 96 (12): p.5585-5595 (C) Serials Publications

Eleukenov Sh. (1997) Adebiet jane ult ruhy [Literature and the fate of the nation]. Almaty. Science p. 368 (In Kazakh)

Encyclopedic Literary Dictionary. (1987) Moscow, Soviet encyclopedia p.751 (In Russian)

Esembekov, T.U., Kozhakanova, M.T. The Social Nature of Literary Translation in Kazakstan in XX Century. Procedia - Social and Behavioral Sciences 114 (2014) p. 229-233

Ospanova A. (2014) The idea of Turkic unity in Kazakh poetry of the early twentieth century. Almaty, Life Science Journal, $11 / 8 /$ p. $207-211$

Ivanov V. (1912) Mysli o simvolizme // Trudy i dni [Thoughts on symbolism // Works and days]. No1. p. 9 (In Russian)

SadykovN., Zhussipova A., Abdimanuly O. (2013) Kazakh Literature in Emigration and Works of Mazhit Aitbayev. World Academy of Science, Engineering and Technology International Journal of Humanities and Social Sciences.Vol:7, No:3, 2013 pp. 690-695

Robert N. Twentieth-century poetry. Blackbell publishing, 2001. - pp. 610.

Compton-Rickett A., (1900) M.A., LL.D. A History of english literature. London:T. C. \& E. C. Jack 67 Long Acre, W.C., and Edinburgh New york: Dodge publishing co, p. 112. 